\title{
REKAYASA PEMBELAJARAN BERDASAR ANALISIS LINGKUNGAN DI TENGAH WABAH COVID-19
}

\author{
Yuni Wijayanti ${ }^{1}$, Sutama ${ }^{2}$ \\ 1,2Universitas Muhammadiyah Surakarta \\ 1yuninugroho88@gmail.com, 2sutama@ums.ac.id
}

\begin{abstract}
corona virus disease (Covid 19) which is affecting the whole world presents its own challenges for educational institutions especially in elementary schools. this makes the school must be able to provide the right facilities in accordance with the conditions so that the development of children at elementary age who are still very dynamic can be maintained. The purpose of this research is the existence of a database that can be taken to determine further policies in the application of learning engineering. The methodology used in this study is this research uses descriptive research with a qualitative approach. The results obtained from the survey can be concluded that the learning media that students like are media books as much as $60 \%$. While face to face as much as $82 \%$, Learning with accompaniment as much as $62 \%$ while the tasks that interest students are voice or voice. So this can help schools determine further mapping for students.
\end{abstract}

Keywords: Covid-19, Learning, Learning Profile

\begin{abstract}
ABSTRAK
corona virus disease (Covid 19) yang melanda seluruh dunia memberikan tantangan tersendiri bagi lembaga pendidikan khususnya di Sekolah Dasar. hal ini membuat sekolah harus mampu memberikan fasilitas yangbtepat yang sesuai dengan kondisi sehingga perkembangan anak di usia SD Ini yang masih sangat dinamis tetap dapat terjaga. Tujuan Penelitian ini adalah adanya database yang dapat di ambil untuk menentukan kebijakan lebih lanjut dalam penerapan rekayasa pembelajaran. Metodologi yang dipakai dalam penelitian ini adalah Penelitian ini menggunakan jenis penelitian deskriptif dengan pendekatan kualitatif. Hasil yang diperoleh dari survey dapat disimpulkan bahwa media belajar yang disukai siswa adalah media buku sebanyak $60 \%$. Sedangkan tatap muka sebanyak $82 \%$, Belajar dengan pendampingan sebanyak $62 \%$ sedangkan tugas yang diminati siswa adalah voice atau suara. Sehingga hal ini dapat membantu sekolah dalam menentukan pemetaan lebih lanjut bagi siswa.
\end{abstract}

Kata Kunci: Covid-19, Pembelajaran, Profil Belajar 


\section{A. Pendahuluan}

Wabah corona virus disease (Covid 19) yang melanda seluruh dunia memberikan tantangan tersendiri bagi lembaga pendidikan khususnya di Sekolah Dasar . untuk melawan covid-19 pemerintah menerapkan berbagai larangan mulai dari larangan untuk tidak berkerumun, pembatasan social (Social distancing) dan menjaga jarak fisik (physical distancing), memakai masker dan selalu mencuci tangan. Berbagai kebijakan dikeluarkan agar pembelajaran tidak membebani orang tua, guru serta siswa yang menjadi bagian utama dalam proses pendidikan (Peraturan Menteri Kesehatan republik Indonesia nomor 9 Tahun 2020 tentang pedoman pembatasan social berskala besar .dalam rangka percepatan penanganan Corona Virus Disease (covid-19)).

Penyesuaian tersebut tertuang dalam Surat Edaran Nomor 2 Tahun 2020 tentang pencegahan dan penangganan Covid-19 di lingkungan kemendikbud, serta surat Edaran Nomor 3 Tahun 2020 tentang Pencegahan Covid di satuan Pendidikan. "Kami mendorong para guru untuk tidak menyelesaikan semua materi dalam kurikulum", papar Menteri Pendidikan dan Kebudayan (Mendikbud) Nadiem Anwar Makarim pada acara media briefing Adaptasi Sistem Pendidikan selama Covid-19. Tujuannya adalah anak memiliki semangat belajar dan karakter yang kuat itu sudah cukup.

Hal ini membuat semua lembaga pendidikan memikirkan cara yang tepat untuk dapat meneruskan proses pembelajaran agar semangat sekolah itu tetap ada pada diri siswa. Apalagi di jenjang SD ini memiliki tantangan besar dimana anak usia SD ini memiliki karakteristik yang unik. Ruickshank mengemukakan beberapa karakteristik umum siswa yang perlu mendapatkan perhatian dalam mendesain proses atau aktivitas pembelajaran, yaitu: (1) kondisi sosial ekonomi, (2) faktor budaya, (3) jenis kelamin, partumbuhan, (5) gaya belajar dan (6) kemampuan belajar. karena di usia ini adalah proses perkembangan di usia golden age itu mulai terjadi sehingga penting sekali keteladanan dan tatap muka (Kompasina: 2020).

Menurut Havighurst tugas perkembangan anak usia SD adalah sebagai berikut :.menguasai keterampilan fisik yang diperlukan 
dalam permainan dan aktivitas fisik, Membangun hidup sehat mengenai diri sendiri dan lingkungan. Belajar bergaul dan bekerja antar teman dalam kelompok sebaya, Belajar menjalankan peranan sosial sesuai dengan jenis kelamin, Mengembangkan keterampilan dasar dalam membaca, menulis, dan berhitung. agar nantinya diharapkan mampu berpartisipasi dalam masyarakat,Mengembangkan konsep-konsep hidup yang perlu dalam kehidupan. Mengembangkan kata hati, moral, dan nilainilai sebagai pedoman perilaku, mencapai kemandirian pribadi (Kompasiana, 2020).

Tugas perkembangan tersebut mendorong guru SD untuk: Menciptkaan lingkungan teman sebaya yang mengajarkan keterampilan fisik, Melaksanakan pembelajaran yang memberikan kesempatan kepada siswa untuk belajar bergaul dan bekerja dengan teman sebaya sehingga kepribadian sosialnya berkembang, Mengembangkan kegiatan pembelajaran yang memberikan pengalaman yang konkret atau langsung dalam membangun konsep, Melaksanakan pembelajaran yang dapat mengembangkan nilai-nilai sehingga siswa mampu menentukan pilihan yang stabil dan menjadi pegangan bagi dirinya. Pendidikan di SD merupakan jenjang pendidikan yang mempunyai peranan sangat penting dalam upaya meningkatkan kualitas sumber daya manusia (SDM

Pada jenjang ini menjadi tolak ukur kesuksesan sebuah pendidikan. Siswa di jenjang SD ini dengan karakteristik yang unik yang tidak bisa kita optimalkan hanya dengan pembelajaran lewat aplikasi online, anak kelas 1 sampai dengan kelas 3 SD membutuhkan penguasaan tentang kerapian menulis, adab yang mulai ditanamkan dan sosialisai dengan lingkungan serta teman sebaya. sehingga perlu melakukan rekayasa pembelajaran yang tepat yang dapat diterapkan di SD sesuai tahap perkembangan, sesuai penelitian yang di lakukan oleh Fitria Susanti, Siswati,Prasetyo Budi Widodo pengaruh permainan tradisonal terhadap kompetensi interpersonal dengan teman sebaya pada siswa sd (Studi Eksperimental pada Siswa Kelas 3 SDN Srondol Wetan 04-09 dan SDN Srondol Wetan 05-08 ) memperoleh hasil bahwa kondisi siswa kelas 3 SD 
membutuhkan

rangsangan

interpersonal

dan

sosialisasi

lingkungan

agar

mampu

mendapatkan hasil belajar yang maksimal.

Selain hal tersebut di atas penting sekali bagaimana kita menyediakan layanan pembelajaran yang ramah orang tua agar orang tua tidak merasa terbebani karena ini penting dimana orang tua ini mengambil peran utama saat Scholl From Home (SFH). Sehingga dengan kita memahami kondisi ini akan terjalin sinegi yang luar biasa antara sekolah dengan orang tua dan siswa yang menjadi obyek pembelajaranpun dapat menikmati serta menjalankan tugas sebagai peserta didik. Tujuan pembelajaranpun tercapai.

Keefektifan

program pembelajaran perlu di petakan awal tentang profil gaya belajar siswa dan kondisi orang tua sebagai data base awal untuk menentukan system pendidikan.

\section{B. Metode Penelitian}

Penelitian ini menggunakan jenis penelitian deskriptif dengan pendekatan kualitatif. Penelitian deskriptif adalah menutur data yang ada. Sedangkan kualitatif merupakan analisis data yang dilakukan yang bersifat induktif berdasarkan faktafakta yang ditemukan kemudian di kontruksikan menjadi sebuah hipotesis atau teori (Affifudin, Beni \&Saebani,2009). Setting Penelitian ini adalah di SD Muhammadiyah Klaten Utara dengan jumlah responden wali siswa dan siswa kelas 1 sampai dengan 6 dengan jumlah siswa 355 siswa.

\section{C.Hasil Penelitian dan Pembahasan}

Proses pembelajaran yang diterapkan di SD Muhammadiyah Klaten Utara di tengah wabah covid 19 ini mengacu pada kondisi yang ada di lingkungan Sekolah. Proses Pengambilan data adalah dengan tekhnik kuosioner berbasis google form, wawancara, observasi dan dokumentasi. Sehingga dari data yang diperoleh dapat menjadikan profil pembelajaran yang di inginkan orang tua dan siswa. Karena kita tidak bisa memaksakan proses pembelajaran siswa dengan keingginan sekolah, ketika hal ini terjadi maka akan membuat siswa dan orang tua merasa aman dan nyaman. Data yang di peroleh 
disajikan dalam bentuk table sebagai berikut:

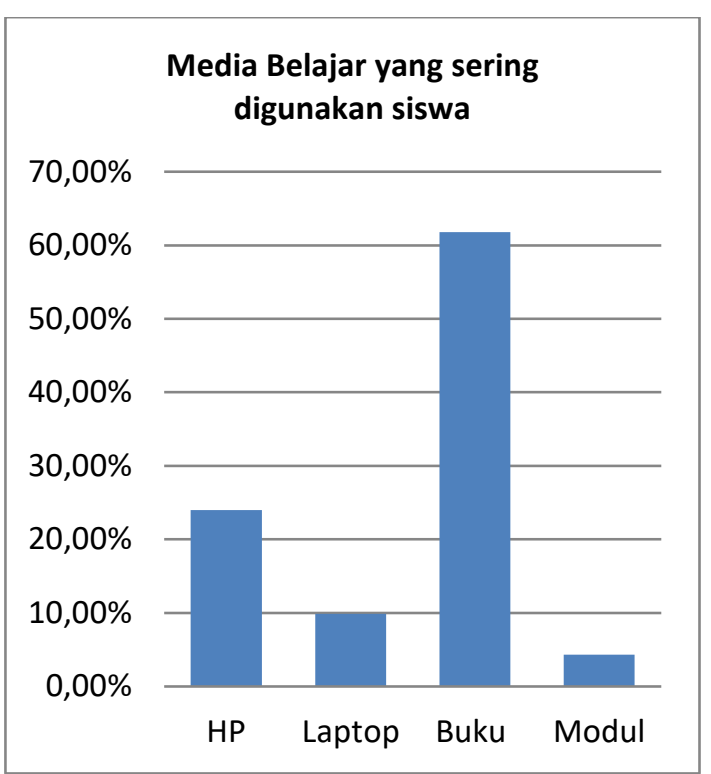

Gambar 1 Media yang paling sering digunakan siswa

Dari gambar 1 di atas dapat di lihat media yang digunakan siswa berbasis HP sebanyak 23,5\%, Modul sebanyak 9,9\%, laptop sebanyak 4,8\% Buku 61,8\%, hal ini dapat di simpulkan bahwa media yang sering digunakan siswa dalam pembelajaran adalah dengan mengunakan buku sebanyak 61,8\%. Media belajar yang digunakan dengan basis Informasi dan tekhnologi masih sangat kurang sehingga sekolah perlu merespon hasil ini dengan menerapkan pembelajaran yang masih mengabungkan luar daring dan daring sehingga tudak hanya berfokus pada tekhnologi yang ada.
Pembelajaran yang di sukai siswa

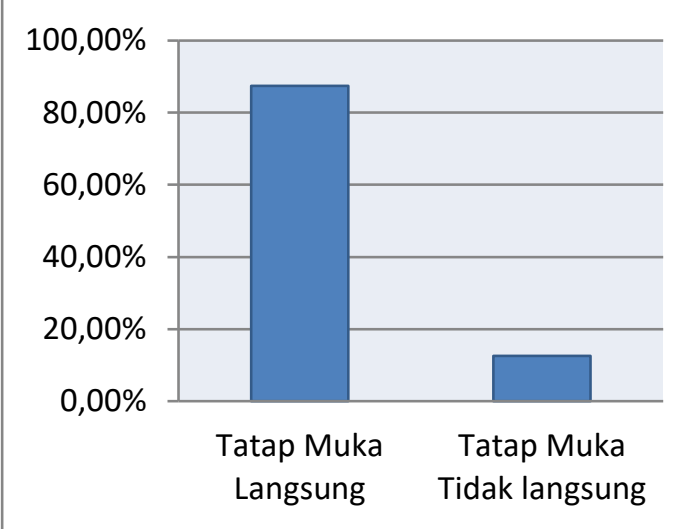

Gambar 2 Pembelajaran yang disukai siswa

Dari gambar 2 di atas dapat disimpulkan bahwa 87,5\% siswa menginginkan pembelajaran tatap muka dan $12,5 \%$ siswa menginginkan pembelajaran daring. Dari hasil ini dapat di tarik kesimpulan bahwa rekayasa pembelajaran yang diterapkan di sekolah walupun berbasis daring harus mampu menjawab keingginan siswa bahwa pembelajaran dilaksanakan secara tatap muka.

Sehingga system pembelajaran yang tepat sesuai dengan profil yang di sampaikan akan lebih cepat tersampaikan. Hal ini adalah wajar dikarenakan anak usia SD masih sangat butuh sekali figure keteladanan yang tidak kita dapatkan dimanapun berada.

Rekayasa pembelajaran yang di terapkan harus mampu melihat kondisi lingkungan sehingga mampu 
menghadirkan pembelajaran yang menyenangkan dan membuat mood siswa untuk belajar hal ini juga di latar belakangi kondisi ekonomi orang tua yang tidak sama antara satu sama lain sehingga dengan adanya profil yang ada ini sekolah harus mampu membuat beberapa rekayasa yang membuat semua peserta didik dan orang tua merasa pendidikan ini nyata ada di tengah wabah covid-19 ini.

Sekolah tidak dapat sendiri kecuali dengan kerjasama orang tua semua saling bersinergi untuk dapat menghasilkan pendidikan yang berkualitas dan mampu tetap eksis di tengah kondisi yang tidak menentu ini.

Strategi yang dapat diterapakan adalah dengan home visit, atau video call lewat wa secara bergiliran dan pengumpulan tugas yang dilaksanakan secara drive thru. Ini mungkin sedikit efektif.

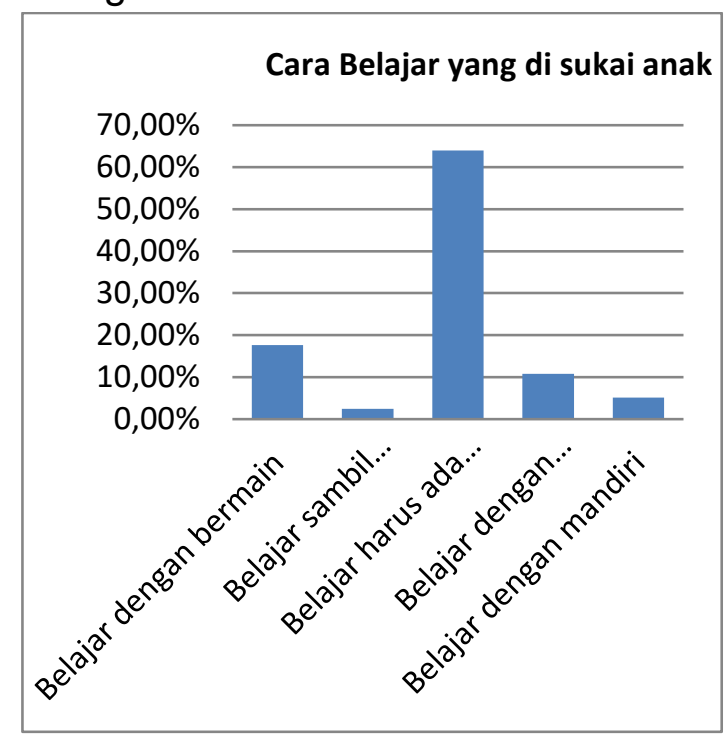

Gambar 3 Cara belajar yang di sukai anak
Dari grafik di atas di peroleh analiis sebagai berikut belajar sambil bermain sebanyak 17,6\%, mendengarkan music 2,5\%,belajar bersama pendamping guru atau orang tua sebanyak 64\%, Belajar dengan kelompok 10,8\%, Belajar dengan mandiri sebanyak $2,5 \%$. Sehingga dapat disimpulkan bahwa cara bealajar yang disukai siswa di SD Muhamadiyah Klaten Utara adalah dengan pendampingan sehingga di sini harus ada kolaborasi antara orang tua dan guru sehingga pendidikan dapat tercapai dengan baik.

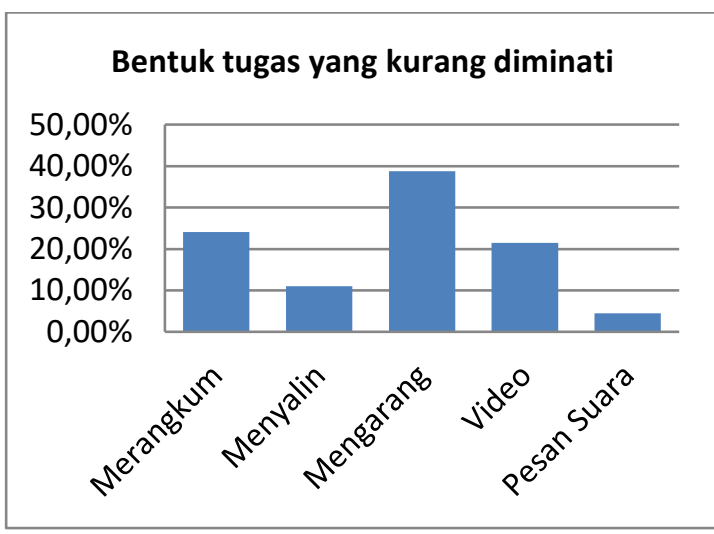

Gambar 4 bentuk tugas yang kurang diminati

Dari grafik di atas di peroleh data tugas yang kurang diminati dari aspek mengarang sebanyak $38,8 \%$, merangkum sebanyak 24,1\%, menyalin sebanyak 11\%, Pesan suara Sebanyak 4,5\%, Video pembelajarn sebanyak 21,5\% 
Didaktik : Jurnal IImiah PGSD STKIP Subang,

sehingga dapat di simpulkan bahwa tugas yang paling diminati siswa adalah dengan voice note atau pesan suara, hasil ini dapat menjadi data base awal bagaimana pembelajaran ini dapat diberikan sehingga tidak menuntut siswa untuk menyukai pada tugas yang sudah disiapkan guru. Hal ini menjadikan guru tahu ketika tidak semua siswa mengumpulkan tugas yang sama di setiap sesi pembelajaran. Hal ini dapat mengurangi kejenuhan siswa karena kita menghadirkan pendidikan yang sesuai dengan apa yang di harapkan siswa.

Hal ini relevan dengan penelitian yang dilakukan oleh siti fatonah dengan judul menumbuhkan kecerdasan majemuk (multiple intelligence) anak dengan men genal gaya belajarnya dalam pembelajaran IPA sd.di peroleh hasil Untuk dapat menumbuhkan kecerdasan majemuk anak, diperlukan pola pembelajaran yang bermacam-macam. Guru juga perlu mengetahui gaya belajar anak, belajar dengan cara mereka sendiri, serta orang tuapun perlu memberikan di rumah, apa yang mungkin tidak didapat anak di sekolah untuk menumbuhkan kecerdasan anak. Sebagian masyarakat, meski mungkin sebenarnya mempunyai kesadaran yang besar dalam pendidikan, menganggap semua individu bias dinilai dengan menggunakan satu takaran seberapa pandai atau bodohnya mereka. CaraGardner mengemukakan bahwa ada 8 cara yang sama pentingnya walau mungkin tidak mencakup semua cara belajar yang ada setidaknya 8 cara ini memberikan gambaran yang lebih nienyeluruh daripada evaluasi yang ada selama ini.

\section{E. Kesimpulan}

Berdasarkan hasil penelitian dan hasil pembahasan dapat di simpulkan bahwa kondisi siswa di SD muhammadiyah Klaten Utara masih menginginkan system luring dan tetap adanya tatap muka yang di kemas dengan kondisi yang ada.

Hal itu di dapat di lihat dari berbagai aspek meliputi media belajar yang disukai siswa adalah media buku sebanyak 60\%. Sedangkan tatap muka sebanyak $82 \%$, Belajar dengan pendampingan sebanyak $62 \%$ sedangkan tugas yang diminati siswa adalah voice note. 
Dapat disimpulkan bahwa pembelajaran yang ada di SD muhammadiyah Klaten Utara masih menerapkan system pembelajaran yang belum berbasis IT. Saran yang bisa di sampaikan untuk sekolah adalah mampu mengimplementasikan setiap model pembelajaran sehingga hakekat belajar siswa di masa pandemic covid 19 ini tetap dapat di rasakan oleh semua warga sekolah.

\section{DAFTAR PUSTAKA}

Sutama. (2019). Metode Penelitian Pendidikan. Sukoharjo: Universitas Muhammadiyah Surakarta.

Hikmat1, Endang Hermawan2, Aldim3, Irwandi4. Efektivitas Pembalajaran Daring Selama Masa Pandemi Covid-19: Sebuah Survey Online, 2020. UIN Sunan Gunung Jati Bandung.

Tedi Priatna1, Wildan Baihaqi2, Asep

Andi Rahman3, Yaya Sunarya4. Reformulasi Tugas dan Fungsi Guru Menghadapi Tantangan Pendidikan Era Revolusi Industri 4.0, 2020. UIN Sunan Gunung Jati.

Sutama. (2019). Metode Penelitian Pendidikan: Kuantitatif, Kualitatif, PTK,MixMethod,R\&D.Surakarta:Ja smine

Hikmat, Endang, dkk., 2020. Efektivitas Pembalajaran Daring
Selama Masa Pandemi Covid-19: Sebuah Survey Online. Bandung: UIN Sunan Gunung Jati

Fitria Susanti, Siswati,dkk. 2010 Pengaruh Permainan Tradisonal Terhadap Kompetensi Interpersonal Dengan Teman Sebaya Pada Siswa SD. Semarang: Universitas Diponegoro.

Ida Bagus Putu Arnyana. 2018. Pembelajaran untuk meningkatkan kompetensi 4c (communication, collaboration, critical thinking dancreative thinking) untukmenyongsong era abad 21 . Bali: Universitas Ganesa

Mochamad Cholily, Windy Tunas Putri,dkk. 2019. Pembelajaran di era revolusi industri 4.0. Malang: Universitas Muhammadiyah Malang.

Ali Sadikin*, Afreni Hamidah. 2020. Pembelajaran Daring di Tengah Wabah Covid-19. Jambi: Universitas Jambi

Tedi Priatna, Wildan Baihaqi,dkk. 2020. Reformulasi Tugas dan Fungsi Guru Menghadapi Tantangan Pendidikan Era Revolusi Industri 4.0. Bandung: Universitas UIN Sunan Gunung Jati

Dindin Jamaluddin, Teti Ratnasih,dkk. 2020. Pembelajaran Daring Masa Pandemik Covid-19 Pada Calon Guru: Hambatan, Solusi Dan Proyeksi. Bandung: Universitas UIN Sunan Gunung Jati

Subarto. 2020. Momentum Keluarga Mengembangkan Kemampuan Belajar Peserta Didik Di Tengah Wabah Pandemi Covid-19. Banten: Universitas Pamulang

Najila Indah, Din Answar Dzuratu. 2020. Analisis Pembelajaran Matematika berbasis daring dengan menggunakan aplikasi google Classroom pada masa 
pandemic covid-19: Sukabumi: Universitas Muhammadiyah Sukabumi.

Dian Ratu, Hascaryo, dkk. 2020. Pendidikan dalam masa pandemic covid-19. Semarang: Universitas Terbuka Semarang.

Johan Ervan, Pramana Admaja, dkk. 2020. Efektifitas Pembelajaran menggunakan moodle terhadap motivasi dan minat bakat peserta didik di tengah pandemic covid-19. Madiun; Universitas PGRI Madiun

Hisny Fajrussalam, Koko Adya Winata, dkk. 2020. Inovasi pesantren ramadhan dalam meningkatkan kecerdasan spiritual peserta didik di masa pandemi covid-19. Bandung: Universitas Sunan Gunung Djati Bandung

Meylan Saleh. 2020. Merdeka Belajar di Tengah Pandemi Covid-19. Gorontalo: Universitas Negeri Gorontalo

Alwazir Abdusshomad. 2020. PengaruhCovid-19 terhadap Penerapan Pendidikan Karakter dan Pendidikan Islam 